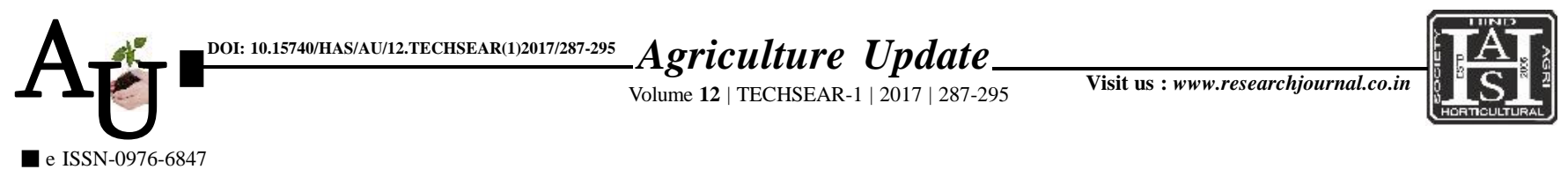

\title{
A Review : An overview of water profile in Tamil Nadu
}

\section{R. KUTTIMANI, A. RAVIRAJ AND B.J. PANDIAN}

Article Chronicle :

Received :

11.07.2017;

Accepted :

26.07.2017

\section{KeY WoRds:}

Surface water,

Groundwater,

Development- critical, Semi-critical, Safe, Command area
SUMMARY : The total water resources available in India are $1859 \mathrm{~km}$, which is roughly 4 per cent of the world's fresh water resources. Tamil Nadu accounts for 4 per cent of the land area and 6 per cent of the population, but only 3 per cent of the water resources of the country. Most of Tamil Nadu is located in the rain shadow region of the Western Ghats and hence receives limited rainfall from the South-west monsoon. The demand for water in Tamil Nadu is increasing at a fast rate both due to increasing population and also due to larger per capita needs triggered by economic growth. The annual per capita water availability in India is about $2200 \mathrm{~m}^{3}$ whereas it is only $750 \mathrm{~m}^{3}$ in Tamil Nadu. As per World standards our State is under water scarcity.Groundwater is the most important water resource on earth. It comprises of the major and the preferred source of drinking water in rural as well as urban areas and caters to $80 \%$ of the total drinking water requirement and $50 \%$ of the agricultural requirement in rural India. The groundwater is a dynamic and replenishable natural resource, but in hard rock terrains its availability is of limited extent and is essentially confined to the fractured and weathered horizons. In Tamil Nadu, more than $70 \%$ of the geological formation is of hard rocks which limit the availability and extraction of ground water unlike other formations. Research studies by various institutions reveal that the percentage of safe blocks has declined from 35.6 per cent to 25.2 per cent while the semi-critical blocks have gone up by a similar percentage. Over-exploitation is occurring in more than a third of the blocks $(35.8 \%)$ while eight blocks $(2 \%)$ have turned saline over the past five years in Tamil Nadu. Henceadoption of groundwater resource developmental activities are compulsoryto handle as well as to meet out the demand in future. And also adoption of improved technologies like micro irrigation,System of Rice Intensification (SRI) and Alternate wetting and drying can greatly reduce the water requirement which also increases the yield.

How to cite this article : Kuttimani, R., Raviraj, A. and Pandian, B.J. (2017). An overview of water profile in Tamil Nadu. Agric. Update, 12(TECHSEAR-1) : 287-295; DOI: 10.15740/HAS/AU/12.TECHSEAR(1)2017/ 287-295.
Author for correspondence :

\section{R. KUTTIMANI}

Water Technology

Centre,Tamil Nadu

Agricultural University, , COIMBATORE (T.N.) INDIA

Email:kuttimanir@ gmail.com

See end of the article for authors' affiliations 